\title{
The Use of Structural Methodology in Postmodern Concepts of Technology
}

\author{
OKSANA CHURSINOVA, SVITLANA POVTOREVA, NATALIIA ZHORNIAK \\ Department of Philosophy, Lviv Polytechnic National University, 5 Mytropolyt Andrei Street, 79013 Lviv, Ukraine \\ Email: churss@ukr.net; vedmedja@ukr.net; nataliazhorniak@gmail.com
}

\begin{abstract}
The article is aimed at defining the possibilities for structural methodology to understand the phenomenon of modern technology. Some principles of postmodernists' structural research are highlighted. The embodiment of these principles in the analytical discourse is shown, considering the state and development of technical activities and how they allow one to assess and predict future events. These predictions about mechanization, informatization and virtualization of almost all areas of modern society are contemplated pessimistic by some thinkers and optimistic by others. The conducted study showed that the structural methodology is a fairly effective means of philosophical understanding of the phenomena of technical reality. More and more people become involved in technology, and it is generally not perceived as involved in global threats. Instead, the dynamics and the consequences of structural transformations in the technical field are deeply interpreted by philosophers, who formulate their predictions and thus signal the dangers to culture and civilization.
\end{abstract}

Keywords: automatics, difference, the obese of structures, structure of technical product, transgression

\section{INTRODUCTION}

In the formation of terminology and outlining the problems associated with the mechanization of society, there is a tendency to use the conceptual apparatus of general scientific approaches (systemic, structural, functional, etc.), which allows one to identify the essence of crisis phenomena in the modern world. Certain achievements of this methodology are associated with a rethinking of the linguistic theory of Ferdinand de Saussure, the creator of structural linguistics (Povtoreva, Chursinova 2018). The focus on the structure of the system allowed one to interpret the crisis in the foundations of modern society. J. Derrida states that structuralist consciousness is catastrophic, destructive and declining (Derrida 2004: 12).

The application of structural methodology elements can be traced in the works of famous representatives of European postmodernism, who are trying to understand the processes of technicalization, cybernetization and virtualization (Baudrillard 1996; Baudrillard 2017; Derrida 2004; Kaplen 2003; Plant 2018; Irigaray 1985; Haraway 2015; Haraway 2017).

Among the variety of methodological principles used in postmodern studies of technical development of society, the authors tried to identify those that belong to the structural 
methodology, considering them to clearly represent the significant trends of our era. Peculiarities of structural methodology were considered in the works of researchers from Slavic countries (Klimenkova 2006; Povtoreva, Chursinova 2018); the connection with the problems of technologicalization of society gained the attention of researchers (Dejneka 2017; Emelin 2016; Kareva, Stolet 2018; Rimkus 2020; Sergeeva 2014). A number of basic principles of the structural approach were identified, by means of which the structures of technical activity are analysed within the framework of gender (Povtoreva, Chursinova 2020) and outlines of some aspects of its application for the analysis of technical phenomena are delineated.

In the structural study of technical phenomena the representatives of postmodernism most often use in their works the principles of structure, differences (variations), the allocation of fundamental structure-forming relations, transgression, etc.

\section{THE PRINCIPLE OF STRUCTURE IN UNDERSTANDING THE PHENOMENON OF MODERN TECHNOLOGY}

The essence of this principle is to define the elements and determine the structure of a particular field as a set of relations. The structure ensures the integrity and functioning of the objects of the studied area. 'The structure defines fixed characteristics, that distinguish what we call a system, from objects of another kind' (Povtoreva 2010: 142).

One of the most original concepts of technology, which applies the principle of structure, belongs to the famous French thinker Jean Baudrillard, who is considered to be the guru of postmodernism. He quite often uses the concept of structure and a number of terms derived from this word. This gives him the opportunity to explain a wide range of phenomena of the modern world.

Based on the principle of structure, the philosopher finds out what in technical devices is structural and what is not structural, that is, what concerns the technical device directly, and what is a formal feature, being a technical trifle. He compares our latest technical era with the Baroque epoch, when the redundancy of forms, unrestrained formalistic creativity and syncretism of elements of different epochs prevailed. Similarly, modern technology, in his opinion, binds all the incitements and myths of the technical era up to a new discursive individualism, rhetoric and allegory (Baudrillard 1996: 113).

J. Baudrillard considers automatics to be an essential feature of modern technology, which is perceived as a model of all technology. What is more, any material object, due to the author, on losing its practical application can be fetishized by both 'primitive' and 'civilised' people (Baudrillard 1996: 117). The philosopher characterises automatics as an excess of structure, a deviation in the development of technology. There are many technical products created in a way, where the obsessiveness over details and secondary functions multiplies thus unrestraining the spread of technical eccentricity. Rational functional expediency is increasingly lost in the creation of technical devices. Instead, one can observe abundance of irrational complication. The objective conditionality of the technical product gives way to fantasies and imaginary technical solutions (Baudrillard 1996: 113).

Using the principle of structure, Baudrillard explains the evolution of mankind and technology. He notes that the development runs parallel at three levels: technical structuring of the thing (convergence and integration of functions, their concretization and economy), structuring of the world and nature (victory over space, energy control, awareness raising, etc.), and 
structuring of human practice towards increasing relativity and mobility, open integration and 'thriftiness' of society in the same way as it happens in the latest technical products. Each of these three levels has its own dynamics, which leads to their inconsistency, resulting in their mutually retarded or frozen development. The technical product, having achieved the desired result, solidifies at this level and then only reproduces this fixed structure. Afterwards this product, such as a car, loses its dynamics as a technical product and begins to function as a supplement to the house. The car and the house become a closed system loaded with conventional human values (prestige, means of domination, mental factors, etc.). The car, instead of serving man for its purpose and structural definition, becomes a hindrance in the development of society (Baudrillard 1996: 130).

The modelling (structuring) influence of the modern social order based on technology and its practical embodiment in industrial production on our civilization is of a dual and contradictory character: at the top, i.e. at the level of design and creation of technology, formative (technological) coherence works providing 'the essential', while at the basis there is a structural (albeit managed) incoherent mechanism of sales of goods and satisfaction of needs overpowered by the inessential (Baudrillard 1996: 189).

In considering the dangers posed by the technical development of mankind, Baudrillard tends to use the principle of structure. He develops the concept of the obese of the structure by which he claims that virtual networks are inflated with a huge amount of information. These networks are characterised by the obesity of operational component, the mania to preserve and memorise everything, to reach the very limits of stocktaking of the world and information and at the same time to introduce such terrible potentiality which is impossible to imagine (Baudrillard 2017: 37). The philosopher compares modern technical systems with the obese human body which loses its normal structure and becomes unviable.

J. Derrida connects meticulous attention to the structure of objects and phenomena of the surrounding world, technical products including, with the crisis nature of the modern era. 'We notice the structure', he states, 'in the case of a threat, at a moment when the approach of danger forces us to stare at the vault of an institution and at the stone in which its ability and its fragility are concentrated' (Derrida 2004: 12). When it comes to technology, as Baudrillard notes, 'all structures are turned inside out, displayed and all actions become visible...' (Baudrillard 2017: 39). The philosopher compares technical networks with cancer and with a metastatic form of death. Modern information systems, like cancer cells, are able to multiply indefinitely, they hold the dead meaning in the living and produce too much sense (Baudrillard 2017: 43). Thus, modern technology aims to destroy the living and thus leads humanity to a disappointing end. The oversaturation of technical means, the intertwining of the living and the artificial, and the increasing interference of the artificial with the living pose the threat of the death of the living and the destruction of humanity.

At the heart of modern society, all the activities of which are entangled in technical products and information networks, there is this swollen structure, which Baudrillard denotes to be a matrix of all forms of structural obesity (Baudrillard 2017: 37). The European philosopher considers such structural bloating to be a characteristic feature of American ghost culture.

\section{THE PRINCIPLE OF DIFFERENCE (VARIATIONS) IN POSTMODERN CONCEPTS OF TECHNOLOGY}

The principle of difference (variations) is substantial in the arsenal of structural methodology. The representatives of this methodology (which largely includes postmodernists) sometimes present it as the basis for non-classical philosophy. They contrast the post-classical philosophy 
of difference with the classical 'philosophy of identity' (Mozheiko 2001). Within this direction the variation 'appears as the basis and possibility of any differentiation, of all kinds of classification, it is a certain state of being, different from another state' (Povtoreva 2010: 162).

J. Baudrillard highlights a number of differences between the model and the series, which differ in sensory qualities, nuances, time and class affiliation. He reveals the new structure of complex technical products, notes the differences between the old, traditional technology and the latest devices. Old equipment, tools and their arrangement structurally reflected the image of man and his presence. Modern sophisticated devices embody superstructurality. Automated products, states the researcher, are no longer designed to imitate gestures, energy, needs and body image, but to reproduce independence of consciousness, ability to control, personality and self-concept (Baudrillard 1996: 112). By automatics a person masks his or her own structural weaknesses, i. e. lack of ability to self-defence and to the influence of external circumstances.

The concept of 'difference' appears as a fundamental methodological principle in women's researches of Butler (Butler 1990), Irigarey (Irigarey 1985) and others.

S. Plant considers weaving as a traditional female occupation, closely woven into the image of a woman and one that was an important component of femininity under patriarchy (Plant 2019). At the same time, it is emphasised that netting and weaving are among the oldest techniques, and that this technique was invented by women. Weaving was not just an occupation, it was an important discovery and invention in the history of culture. The woman weaver imitates nature, demonstrates artificiality and plays her own role. 'A woman can seem to imitate nature and create a duplicate of what nature envisions and produces. A kind of technical support and replacement' (Irigarey 1985: 115). The intrusion of mechanization into these occupations leads to significant time savings, reduces labour costs, but causes the destruction of family relationships and destroys the traditional femininity identity. It was rather a man, not a woman who was a subject of cultural history. However, the role of women is not insignificant. She was a mirror, a servant, a man's home, his tools, means of communication and the ability to reproduce his species and his world, she was a natural resource that belonged to man and provided his cultural progress.

\section{SELECTION OF ELEMENTARY AND FUNDAMENTAL STRUCTURE-FORMING RELATIONS}

An important principle of structural research is the requirement to identify 'fundamental structure-forming relations' (Povtoreva 2010: 154). The starting point of such a study is the selection of units of structure, a kind of 'cell, i.e. the elementary structure-forming relationship of this area of research. The beginning of this was laid by structural linguistics of Ferdinand de Saussure, who considered the phoneme to be an elementary structural relation, followed by Claude Lévi-Strauss, who introduced the concept of mythology into scientific circulation, considering it a cell that allows one to study myths from the standpoint of integrity. 'Structural research conducted with the help of such units', states the Ukrainian researcher S. Povtoreva,'seeks to identify the most significant relationship of the subject area in which the analysis is carried out' (Povtoreva 2010: 155). Elementary and fundamental relationships are interrelated within a structural methodology. The fundamental structure-forming relation reflects the main contradiction of the object under study.

Following this principle Baudrillard tries to identify both the elementary and fundamental relations in the field of the technical. Automatics appears as such a unit. Modern technical 
devices, according to the philosopher, increasingly express the goal of man 'to become a fully autonomous monad' (Baudrillard 1996: 112). The technical thing is tuned to its own existence, it is a projection of the autonomous human consciousness. However, automatics, which is still associated with man and his form (structurality), undermines the specific structural feasibility of technology, its ability to develop and positively change people's lives. Baudrillard also characterises this cell as an operational molecule, which 'awaits only a predetermined by some code development and endless reproduction in completely identical copies' (Baudrillard 2006: 45), i.e. cloning.

G. Deleuze singles out a peculiar unit of analysis in postmodernism. He identifies an empty cell (empty space) as an elementary relationship in the structure. This cell breaks the structure as a whole, which causes this structure to change. 'Such a cell appears under different names in the concepts of most representatives of postmodernism and is an important aspect of its epistemology' (Povtoreva 2010: 158). This is 'the place of the card idol, the place of the king, the blind spot, the floating sign, the zero value, the backstage part of the scene, the absence of reason, etc.' (Badiou 2004: 54). The empty space is mobile, passes from one structure to another, creates the possibility of combinatorics, change and development.

In the works of J. Baudrillard we find reasoning on the subject of an empty cell in an open system, thanks to which a real and useful evolution of technology is possible. In fact, the perfection of machines, which increases their technicality, is neither due to greater automatism nor to the saturation of secondary structural elements, but to a certain degree of uncertainty, due to which the machine becomes sensitive to new information. Such a fruitful uncertainty (empty space) is created by man. The philosopher uses the concept of open structure, in which there will always be a place for man as its main element, which creates the dynamism of technology and further development of man as a creative agent and safeguard to prevent the death of civilization, i.e. self-destruction. 'A high-tech machine', says Baudrillard, 'is an open structure, and, taken as a whole, such open machines presuppose the presence of a person, a living organizer and interpreter' (Baudrillard 1996: 111).

Baudrillard defines the contradiction in man's understanding of the perfection of technology and the actual conditions for its improvement as a fundamental structural relationship. Increasing the role of automation as the saturation of the technical device outside the structural elements (secondary functions) meets the desire of a man to make everything work presumably by itself, as if the machine performs its function with minimal human effort, even in a way where man is not visible in the process. From this point of view, we are quite indifferent to the structure and function of automatics (automatic devices). This desire is an irrational desire for formal perfection, it creates a 'material obstacle to the open structuring of our technical means and needs' (Baudrillard 1996: 111). Therefore, the seemingly appropriate desire of a person to use technology to minimise their efforts in many areas of activity turns into its opposite and becomes not only useless, but also poses significant threats to nature and humanity.

Analysing the crisis state of technical development of modern Western civilization, Baudrillard tries to identify the cell through which destructive processes occur. It is a structural unit, a molecule, a closed cellule capable to divide and multiply to infinity and to monopolise all information (Baudrillard 2017: 37). Such uncontrolled, irrational reproduction, similar to cancer, is not the obesity of some individuals, bodies, technical devices, it is the structural obesity of the social system itself, of the whole culture, it is its devaluation and decline. 


\section{THE PRINCIPLE OF TRANSGRESSION IN THE POSTMODERN DISCOURSE OF TECHNOLOGY}

This principle is connected with overcoming borders and going beyond established structures, structural understanding of difference, as boundaries are created only on the basis of difference. Their transition and overcoming is released through the realization of the boundaries of discursive formations. Boundaries created within the dominance of traditional discourse can be subjected to and redefined through various forms of transgression (Agazzi 2009: 81).

Donna Haraway develops an original concept of technologicalization of modern society in the context of feminist research in science and technology. She seeks opportunities to use feminist ideas to change the traditional male patriarchal discourse in order to reverse the usual orientations of social practice against themselves through its destruction. Haraway defines the boundaries of science, culture, technology and seeks a place of feminist criticism and practical action to construct a better future.

D. Haraway understands transgression as overcoming the boundaries of permanent structures, which figuratively and literally symbolises how power fits differently into the body, culture, space, earth and spirituality. She believes that it is not enough to simply abolish traditional gender polarities. It is necessary to go beyond the established limits while taking responsibility for changing the old and building new borders. This formulation had a devastating effect on the traditional discursive structures of Western societies. The feminist community gradually realised that dualisms (traditional oppositions) are inseparable from patriarchal traditions, which oppress women, the coloured and workers, and create ecological threats to the natural environment. It is necessary, according to Haraway, to realise that gender, racial and class consciousness is the result of history, the tragic experience of patriarchy and the capitalist system, which multiplies social contradictions on a global scale.

The most popular work in the Western humanitarian discourse was that of D. Haraway titled 'Cyborg Manifesto: Science, Technology and Socialist Feminism of the 1980s' (Haraway 2017). With the publication of the Manifesto, a new direction of gender research is being formed, namely, cyberfeminism. This is not a critique of patriarchy or a search for identity change through language, it is a transgressive synthesis of technics, science, technology and humanism. The popular notion of the universality of capitalism as a social order, of its merging with technics and technology, as well as of the complete dependence of man on technology is refuted. Haraway emphasises that the scientific and technological development of mankind should be closely connected with the humanistic consciousness of society, which is significantly formed by women and other people, who in the modern world are not yet recognised as gender equal. Cyberfeminism creates new communities united by resistance to the aggression of technocapitalism (Kareva, Stolet 2018: 33).

Haraway sees a real opportunity to overcome borders in the technical development of society and high-tech culture, which challenges all kinds of dualism. In cybernetic reality, the differences between the creator and the created are insignificant; in the relationship between humans and machines the difference between a man and a woman is unclear. The symbolism of cyborgs helps to overcome the oppositions of the traditional discursive structure that we use when we want to find out for ourselves how we carry out our activities. Machines both build and destroy the identity of people, categories and social relations. She suggested imagining an alternative reality in which people would identify themselves with cyborgs, a new, genderless class. The Manifesto has become one of the program texts of postgenderism, a movement aimed at eradicating social inequality by erasing gender differences. 
Haraway considers her work on cyborgs to be a myth about the crossed borders, which are overcome by associations of progressive people and about new opportunities for research and political work (Haraway 2017).

Due to digital technologies, the Internet, and the virtual environment, differences in physicality are gradually disappearing. Modern technologies allow you to choose gender and identity, and overcome the boundaries between people and technical devices, between men and women. The technology of the industrial age contributed to the patriarchal structure of communities, while network technologies are forming the foundations of another society in which there will be no place for inequality of different strata. Haraway believed that such a humanistic society could be created by 'making the most of the potential of technological science' (Sergeeva 2014: 149).

The principle of transgression is used in Baudrillard's works too. The philosopher believed that reality manifests itself as a whole created by structure. Denial of reality occurs 'not in the process of primitive destruction, but through destructuring; it is this procedure that ensures that it goes beyond any possible systems' (Baudrillard 2006: 138). With such transgression, he insisted, we get to the other side of the real, where things are revealed to us directly, as they really are.

At the same time, according to the philosopher, the excess of structure going beyond its borders and the transgression beyond the organic for technology structure open a whole world of functionalist delusion and aimless formalism that Baudrillard gives an example of such a common technical product as a car. Old cars with a manual drive are old-fashioned, and modern cars without a drive with automatic devices are more complex and seem more comfortable. However, automatics actually 'masks their structural weakness' (Baudrillard 2001: 121). This imperfection, according to the philosopher, is structural in nature. He considers automatic vehicle and car decorations to be of secondary functions, those which are redundant in the car. Designers install many non-structural elements in the form of excess automatics into the modern cars, which is considered to be a sign of technical excellence and technical progress in general. However, structurally, these products are less reliable, fail faster and require repair and replacement of elements.

\section{CONCLUSIONS}

1. Structural methodology plays an important role in the philosophical understanding of technology. The application of a number of its principles (structure, differences, selection of elementary and fundamental structure-forming relations, transgression, etc.) allows one to reveal the essence of modern technology and to clarify the directions and prospects of structuring the technical sphere in its synchronous and diachronic dimensions, i.e. aspects of functioning and development.

2. Spreading the concept of structure and the combinations with this term in contemporary postmodern discourse which concerns technology demonstrates the crisis in this area, because the interest towards structure is awakened in times of hardship. In their technical activity, people create outward-facing networks that permeate almost all areas of life in modern developed societies, and this, according to postmodernists, is a sign of a threatening situation in the whole system of our civilization.

3. The representatives of Western philosophy, while studying the situation with technology, see the prospects of total invasion of technology into human life and society in various ways. European philosophy is characterised by pessimistic forecasts. The structure of 
the technology is characterised as obese, incapable of internal improvement, closed and prone to endless reproduction and metastasis, similar to cloning (Jean Baudrillard). The dense intertwining of the living and artificial (technology) mutually inhibits their own structuring, as well as the further positive development of technology, human, society and nature. In American philosophy, in cyberfeminism in particular, modern technological development is assessed positively ('Cyborgs will save the planet!'), it is the one that can change society for the better and will effectively confront the global problems of today. 'Over a couple hundred years from now', predicts Donna Haraway, 'maybe the human people of this planet can again be numbered two or three billion or so, while all along the way being part of increasing well-being for diverse human beings and other critters as means and not just ends' (Haraway 2015: 165).

Received 26 May 2021 Accepted 2 July 2021

\section{References}

1. Agazzi, E. 2009. 'Rethinking Philosophy of Science Today', Voprosy Filosofii 1: 40-52.

2. Badiou, A. 2004. Deleuze. The Noise of the Existance. Trans. D. Skopin. Moskva: Logos-Altera.

3. Baudrillard, J. 1996. System of Objects. New York: VERSO.

4. Baudrillard, J. 2006. Passwords. From Fragment to Fragment. Trans. N. Suslova. Ekaterinburg: U-Faktorija.

5. Baudrillard, J. 2017. Fatal Strategies. Trans. A. Kasalova. Moskva: RIPOL klassik.

6. Butler, J. 1990. Gender Trouble: Feminism and the Subversion of Identity. New York: Routledge.

7. Dejneka, A. 2017. 'Queer Theory on the Opposite Side of Constructivism and Essentialism: Is it Possible to Eliminate Binary Thinking?', Aktualni problemy sotsiolohii, psykholohii, pedahohiky 2(33): 80-88.

8. Derrida, J. 2004. Writing and Difference. Trans. V. Shovkun. K.: Osnovi.

9. Emelin, V. 2016. 'Simulacra and Virtualization Technologies in Information Society', Socialnaja Psihologija. Nacionalnyj Psihologiceskij Zurnal 3(23): 86-97.

10. Haraway, D. 2015. 'Antropocene, Capitalocene, Plantationocene, Chuthulucene', Environmental Humanities 6(1): 159-165.

11. Haraway, D. 2017. Cyborg Manifest: Science, Technology and Socialist Feminism of 1980ies. Trans. A. V. Garadzha. Moscow: Ad Marginem Press.

12. Irigaray, L. 1985. Speculum of the Other Woman. New York: Cornell University Press.

13. Kaplen, E. 2003. 'Women's Studies', trans. V. Shovkun, in Enciklopedija postmodernizmu. K.: Osnovi, 154-163.

14. Kareva, L.; Stolet, J. 2018. 'Cyberfeminism: Bodies, Networks, Interfaces', Khudozhestvennyj Zhurnal 105: 33-39.

15. Klimenkova, T. 2006. 'The Meaning of Methodology: Three Main Approaches', in Genderna Pedagogika, ed. V. Gajdenko. Sumi, 48-68.

16. Mozheiko, M. 2001. 'Transgression. Postmodernism', in Encyclopedia. Minsk, 842-843.

17. Plant, S. 2018. 'Weaving Looms of the Future: Weaving Women and Cybernetics', trans. L. Kareva. Available at: https://syg.ma/@lika-kareva/sedi-plant-tkatskiie-stanki-budushchiegho-tkachiestvo-zhienshchin-i-kibiernietika-1/ (accessed 04.04.2018).

18. Povtoreva, S.; Chursinova, O. 2018. 'Comparative Analysis of Bakhtin's and Saussure's Approaches in the Context of Structuralism and Poststructuralism', Filosofija. Sociologija 29(3): 158-166.

19. Povtoreva, S.; Chursinova, O. 2020. 'Transgression and the Search for Identity in the Context of Gender Problem and Cyberfemenizm', Visnik Harkivsk. Nacion. Un-tuIm. V. N. Karazina. Serija Filosofija. Filosofski peripetii 62: 33-46.

20. Povtoreva, S. 2010. Structural Approach - Structuralism - Poststructuralism (Evolution of Methodology and its Popularization in the Humanitarian Studies). Lviv: Vid-vo Nacionalnogo Universitetu Lvivska Politehnika.

21. Rimkus, E. 2020. 'Technique, Technologies, Ontology: Philosophical, Sociological and Communicative Aspects', Filosofija. Sociologija 31(3): 261-270.

22. Sergeeva, O. 2014. 'Enslaving Screen, Liberating Screen: Theorists of Feminism on Media Technology', Nauka Televidenija 11: 145-154. 
OKSANA CHURSINOVA, SVITLANA POVTOREVA, NATALIIA ZHORNIAK

\title{
Struktūrinès metodologijos naudojimas postmoderniose technologijos sąvokose
}

\begin{abstract}
Santrauka
Straipsnio tikslas - apibrèžti struktūrinès metodikos galimybes suvokiant šiuolaikinių technologijų fenomeną. Išryškinami kai kurie postmodernistų struktūrinių tyrimų principai. Pateikiamas šių principu ịkūnijimas analitiniame diskurse, atsižvelgiant ị techninès veiklos būklę ir raidą bei ị tai, kaip jie leidžia ịvertinti ir numatyti būsimus ịvykius. Šias prognozes apie beveik visų šiuolaikinès visuomenès sričių mechanizavimą, informatizavimą ir virtualizavimą vieni mąstytojai laiko pesimistinèmis, kiti - optimistinèmis. Atliktas tyrimas parodè, kad struktūrinè metodologija yra gana veiksminga priemone filosofiniam techninės tikrovès reiškinių supratimui. Vis daugiau žmonių ịsitraukia ị technologijas, o tai paprastai nesiejama su pasaulinėmis grèsmėmis. Filosofijos struktūrinių transformacijų dinamiką ir pasekmes iš esmès interpretuoja filosofai, kurie formuluoja savo prognozes ir taip signalizuoja apie pavojus kultūrai ir civilizacijai.
\end{abstract}

Raktažodžiai: automatika, skirtumas, konstrukcijų didejjimas, techninio produkto struktūra, transgresija 